\title{
Correction to: Does the Realisation of Children's Rights Determine Good Life in 8-Year-Olds' Perspectives? A Comparison of Eight European Countries
}

\author{
Dagmar Kutsar $^{1}$ - Kadri Soo ${ }^{1}$ - Tomasz Strózik ${ }^{2}$. \\ Dorota Strózik $^{3}$ • Brindusa Grigoraș ${ }^{4} \cdot$ Sergiu Bălțătescu $^{5}$
}

Published online: 1 May 2018

(C) Springer Science+Business Media B.V., part of Springer Nature 2018

\section{Correction to: Child Ind Res \\ https://doi.org/10.1007/s12187-017-9499-y}

The original version of this article unfortunately published online with omitted acknowledgement statement.

The added acknowledgement statement is shown below.

\section{Acknowledgments}

The article was written with the financial support from Estonian Research Council (PUT 1530) and National Science Centre (DEC-2015/19/D/HS4/00402) in Poland.

The online version of the original article can be found at https://doi.org/10.1007/s12187-017-9499-y

\section{Dagmar Kutsar \\ Dagmar.kutsar@ut.ee}

Kadri Soo

kadri.soo@ut.ee

Tomasz Strózik

Tomasz.Strozik@ue.poznan.pl

1 Institute of Social Studies, University of Tartu, Lossi 36, 51003 Tartu, Estonia

2 Department of Business Activity, Poznań University of Economics and Business, Al.

Niepodległości 10, 61-875 Poznań, Poland

3 Department of Statistics and Demography, Poznań University of Economics and Business, Al. Niepodległości 10, 61-875 Poznań, Poland

4 Babeș Bolyai” University Cluj-Napoca, Bd 21 Dec. 1989 nr, 128 Cluj Napoca, Romania

5 Department of Sociology and Social Work, University of Oradea, Str. Universității nr. 1, Oradea, Romania 